\title{
THE HERSFELDENSIS AND THE FULDENSIS OF AMMIANUS MARCELLINUS: A RECONSIDERATION
}

\author{
Gavin Kelly and Justin Stover ${ }^{\star}$ \\ University of Edinburgh, UK \\ All Souls College, Oxford, UK
}

The only two authoritative manuscripts of Ammianus Marcellinus to survive to the present day were produced in Germany in the first half of the ninth century: Vaticanus Latinus 1873 from Fulda (V), and a fragmentary manuscript from Hersfeld now preserved in Kassel (M). This article challenges the consensus that $\mathrm{V}$ is a copy of $\mathrm{M}$. Taking into account recently uncovered fragments of $\mathrm{M}$ (new transcriptions of which are offered in the Appendix), we argue that both are copies of the same damaged original, and discuss the implications for the editing of Ammianus and for our understanding of Carolingian scholarship.

\section{Introduction}

It is generally agreed that, of the sixteen extant manuscripts of the Res gestae of Ammianus Marcellinus, only two, both Carolingian, have any independent authority for reconstructing the text. One of these, from Fulda, was rediscovered by Poggio Bracciolini in I4I $^{7}$ (the same year as his recovery of Lucretius), was brought to Italy, and remains in the Vatican as Vat. Lat. $1873=\mathrm{V} .{ }^{\mathrm{I}}$ The Fuldensis is the ancestor of the fourteen manuscripts from the fifteenth and sixteenth centuries. Poggio also learned of an ancient manuscript of Ammianus at the abbey of Hersfeld, but he never acquired it. ${ }^{2}$ In 1533, the abbot of Hersfeld lent this manuscript, which already lacked at least book $3^{\mathrm{I}}$ and the end of book

^ Email: Gavin.Kelly@ed.ac.uk, justin.stover@classics.ox.ac.uk

This article was conceived at All Souls College, Oxford, in Michaelmas Term 2014; Gavin Kelly would like to express his thanks to the Warden and Fellows for the invitation to join them as a Visiting Fellow, as well as to the Alexander von Humboldt Foundation for support at the time of the article's completion. Justin Stover would like to thank Michael Allen, George Woudhuysen, David Gura, Erik Kwakkel, Mike Kestemont and Mariken Teeuwen. Both authors are grateful for the acute observations of CCJ's anonymous referees.

I This manuscript can be seen online at http://digi.vatlib.it/view/MSS_Vat.lat.1873/ (accessed 7 June 20I6, as were the other URLs in this article).

2 Poggio, Letters I.73 Harth (I.3.12 Tonelli) and I.28 Harth (I.3.29 Tonelli). 
30, to the publisher Hieronymus Froben of Basel, for use in an edition overseen by Froben's corrector Sigismundus Gelenius (Zigmund Hrubý z Jelení): although Gelenius patently relied heavily both on earlier editions and on his own conjectural skills, unmistakable evidence of the Hersfeldensis' contribution comes in the restoration of a long passage of Greek at 17.4.I8-23, omitted by the Vaticanus and its descendants, and of eleven further scattered lines of authentic text omitted by V. ${ }^{3}$ The reason we need evidence for the Hersfeldensis' contribution is that no scholar saw it again until six more or less complete pages from books 23, 28 and 30 were rediscovered and published in 1876. The manuscript had been taken apart in the late sixteenth century; the pages that were rediscovered had been used for binding account books in the castle of Friedewald, 7 miles from the monastery of Hersfeld. ${ }^{4}$ The six pages were found, and for half a century remained, in the archive at Marburg (hence the siglum M); in 1923 they were moved to the Landesbibliothek at Kassel. In the I98os, part of a bifolium from book I8 of the Hersfeldensis was discovered, also at Kassel, in the binding of a manuscript of Ps.-Paracelsus and other works assembled before 1603 . These fragments were published in 1990, without provoking much reaction. ${ }^{5}$

The two manuscripts are very close in both text and date. $\mathrm{M}$, written on vellum in a handsome script, seems to be in the same principal hand in all the extant sections, ${ }^{6}$ in books $18,23,28$ and 30 , with a few unobtrusive changes by subsequent hands. ${ }^{7}$ The page

3 Cf. Froben's introduction: 'Nos nacti uetustum exemplar manu descriptum innumera loca castigauimus, lacunas aliquot expleuimus, scribarum incuria praetermissas, et in his uersus interdum integros restituimus, graeca omnia quae uel prorsus aberant, uel sic aderant, ut frustra adessent ... reposuimus.' The work ended at 30.9.6, with the editorial note 'reliqua in archetypo desiderantur'. On Gelenius see Petitmengin (2006); and on his method in editing Ammianus most recently Den Hengst (2010). The restored lines of text are at 22.I.2-3, 22.10.3, 22.16.7, 24.6.IO-II, 24.7.2, 24.7.3, 25.4.18, 26.7.I6, 27.3.3, 30.5.II (the second passage includes 83 characters, presumably 2 lines; the rest are between 40 and 49 characters long).

4 Nissen (1876); Kassel Landesbibliothek $2^{\circ}$ Ms. philol. 27. Robinson (1936) published photographs of these pages, but they can now most clearly and conveniently be viewed at http://orka.bibliothek.uni-kassel.de/viewer/image/ I336391032501/I/LOG_0ooo/. Given the discovery of additional fragments (see next note), we number these pages not, as Robinson did, by giving each side a number from I to xil, but rather as the third to eighth of the eight surviving folios: $3 \mathrm{r}($ formerly $\mathrm{I})=23.6 .37-4 \mathrm{I}, 3 \mathrm{~V}(\mathrm{II})=23.6 .4 \mathrm{I}-5 ; 4 \mathrm{r}(\mathrm{III})=28.4 .2 \mathrm{I}-5,4 \mathrm{~V}(\mathrm{IV})=28.4 .25-9$; $5 \mathrm{r}(\mathrm{v})$ $28.4 \cdot 3 \mathrm{O}-3,5 \mathrm{v}(\mathrm{vI})=28.4 \cdot 34-28.5 .2$ (the first seven lines on each side have been cut from this folio); $6 \mathrm{r}(\mathrm{vII})=$ 28.5.II-6I), 6v (VIII) = 28.6.I-5; $7 \mathrm{r}(\mathrm{Ix})=30.2 .5-\mathrm{IO}, 7 \mathrm{v}(\mathrm{x})=30.2 . \mathrm{IO}-30.3 .2$ (this folio, which with fol. 8 formed the central bifolium of a gathering, has been cut vertically so that about a third of the text is lost, at the start of the line recto and at the end of the line verso); $8 \mathrm{r}(\mathrm{xI})=30 \cdot 3 \cdot 2-5,8 \mathrm{v}(\mathrm{xII})=30 \cdot 3 \cdot 5-30.4 \cdot 2$.

5 The fragments, for which we also use the siglum M, cover individual words from I8.5.I (Ir) and 3 (Iv), I8.6.I2-I5 (2r) and I6-I7 (2v); they form a bifolium which, one can calculate from the gap between the passages, would have represented the third and sixth folios of a quaternion. See Broszinski and Teitler (1990), with photographs; shelf mark $4^{\circ}$ Ms. chem. 31. Superior images (which enable a few more letters to be deciphered than by Broszinski and Teitler) can be found at http://orka.bibliothek.uni-kassel.de/viewer/image/134096408740I/386/LOG_0028/. For a fresh transcription see the Appendix below.

6 Thus Robinson (I936) IIg and n. I4, contra Nissen (I876) I5, who identified three different hands: however, what he really seemed to identify was different practice in abbreviation (q. for que is used in the fragments from book 30 but not before). Letter-forms and line-lengths (on which more below) suggest the same scribe in all four sections.

7 Most of these are not much later than the original (on these more below), but one particular set of corrections in a Renaissance hand coincide with Gelenius' edition, are consistent with his handwriting, and include a shared error (M 4v, ll. I3-I4 (28.4.26): bos to bonum, nouunt to norunt and (the error) fructuosum sit to fructuosum. sic). In all of our 
size was originally c. $3 \mathrm{I} \times 24 \mathrm{~cm}$ with a written area of just under $20 \times 15 \mathrm{~cm}$. There are 24 lines per side (fol. $7 \mathrm{r}$ has 23), of an average of 46 characters per line, with a range from 35 to 56 ; the average number of characters per page is just under I,IOo. The extant text is relatively free of abbreviations other than q. for -que in the later folios, and suprascript final $m$, usually at line-end. $\mathrm{V}$ is written on vellum (208 folios of an original $2 \mathrm{IO})^{8}$ by a number of different scribes of varying ability, and contrasts in its functional appearance to the calligraphy of the surviving parts of $\mathrm{M}$. The manuscript was checked in the period when it was written, and seemingly against the exemplar, since a number of missing lines are restored in the margins, missing words restored in the margins or in lacunae left in the text, and other small corrections carried out. There are also plentiful humanist variant readings, marginalia and clarifications of punctuation, letters and word-division, in hands including those of Poggio, Niccolò Niccoli and Biondo Flavio: there is no evidence that the humanist variants are anything but conjectural. ${ }^{9}$ The page size is $28 \times 24 \mathrm{~cm}$, and the written area about $20 \times 18 \mathrm{~cm}$. There are usually 27 or 28 lines a page, with a considerably higher number of characters per line than in $M$ and between one and half times and twice the characters per page, depending on the scribe. On the whole, the scribes of $\mathrm{V}$ are considerably more prone to use of abbreviations than that of $\mathrm{M}$, including some curiosities that caused havoc in Renaissance copies. ${ }^{\text {Io }}$ One notable feature of both manuscripts is that spaces of varying lengths are left to indicate lacunae in the text, which in $\mathrm{V}$ can be of a few letters or several lines (for example, in book 29, $\mathrm{V}$ has a succession of lacunae of c. 3 lines each). ${ }^{\text {II }}$ As a rule, the spaces in $M$ have the same basic shape and approximate length as in the equivalent part of $\mathrm{V} .{ }^{\mathrm{I2}}$ As far as the date of the two manuscripts is concerned, palaeographical judgements have for the most part placed them very close to each other, with $M$ perhaps associated with a very slightly later period. Thus, Bernhard Bischoff dates $\mathrm{V}$ closely to the first third of the ninth century and $\mathrm{M}$ to the first half. ${ }^{\text {I3 }}$

Palaeographical consensus, then, places the two manuscripts close enough in time for such criteria to be effectively ignored in assessing their relationship. As well as being close in date and provenance, they are also very close in their text, being full of shared

collations, $\mathrm{M}^{\mathrm{a}}$ indicates the earliest corrector of $\mathrm{M}, \mathrm{M}^{\mathrm{b}}$ any of the several later ones. 'R.' followed by a Roman numeral refers to the collation of $\mathrm{M}$ and $\mathrm{V}$ by Robinson (1936) I2I-6.

8 A bifolium in the final book (covering 3r.8.5-31.I0.I8) was lost after extant copies had been made but before folio numbers were added, between the current folios 200 and 20I (Pellegrin (I99I) 45I, silently correcting earlier scholarship which refers to the loss of a folio). This was the middle bifolium of a gathering of three sheets running from fol. 199 to the current fol. 202: we thank Dr Matthew Hoskin for checking this detail.

On second hands from the Renaissance see Cappelletto (1978), (I98I) and (1983) 165-74; on the conjectural nature of these texts see the brief remarks of Baehrens (I925) 56-7 and Seyfarth (1962) 8-9.

E.g. Ir for autem, $\ni$ for eius. See Clark (1904) 55-8.

Cf. Kelly (2015). experts consulted by Nissen (I876) I5-I8. 
errors and lacking major divergences. There have always been two main possibilities for their relationship, a topic debated even before the rediscovery of the six pages of the Hersfeldensis: either that $\mathrm{M}$ and $\mathrm{V}$ were direct copies of the same exemplar, or that $\mathrm{V}$ was a direct copy of $\mathrm{M}^{\mathrm{I}}{ }^{4}$ The reverse relationship is ruled out by Gelenius' addition from $\mathrm{M}$ of authentic passages not in $\mathrm{V}$; a third possibility, that $\mathrm{V}$ is descended from $\mathrm{M}$ through one or more intermediaries, has never been seriously entertained. Both of the main possibilities had their advocates, the former winning the support of Charles U. Clark in his great edition of 1910-I5. ${ }^{15}$ In 1936, however, Rodney P. Robinson published an article in University of Missouri Studies which argued in detail for the latter case; and his arguments have been taken as conclusive by all who have considered the question since, in particular the Teubner editor Wolfgang Seyfarth, and have been canonised by Leighton Reynolds' judgement in Texts and Transmission that 'Robinson demonstrated as cogently as could be demonstrated that $\mathrm{V}$ was copied from $\mathrm{M}^{ }{ }^{\mathrm{I}}{ }^{\mathrm{T}}$

Robinson could offer no single knockout argument. His method was a close collation of the passages of the entire extant portions of $\mathrm{M}$ against $\mathrm{V}$. In places where they disagreed (trivially for the most part) and one reading was clearly better than the other, he found that $\mathrm{M}$ preserved the truth, or was closer to it, in 50 cases out of 55 . The other 5 cases are as follows:

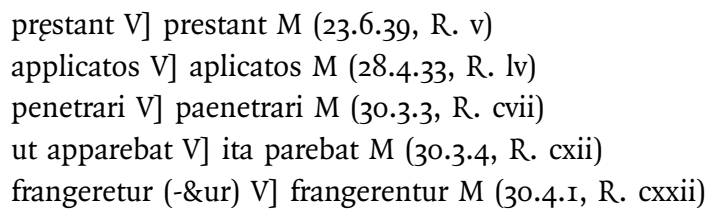

Rightly dismissing the first three of these as orthographical trivialities, Robinson argued that the other two could be seen as easy corrections. He went on to suggest various places in which idiosyncratic details in the physical appearance of $M$ could have led to error in $\mathrm{V}$, and to argue that other errors in $\mathrm{V}$ need not imply an archetype other than $\mathrm{M}$. After some comments on word-division (or its absence), he concluded by suggesting that the length of lines of the archetype of $\mathrm{V}$, as inferred from passages of text omitted in copying and then inserted in the margin, was consistent with what can be inferred about the length of lines in $M$. In what follows we shall add the evidence of the new fragmentary bifolium from book $\mathrm{I}$, showing that it offers further cases of error in $\mathrm{M}$ that are not found in V (section II; see also the Appendix). We shall then go through the case

I4 As already clearly expounded by Mommsen (I872) 23I-2, among others.

I5 Clark (I9IO-I5) I.iv-v; cf. the arguments (incisive but unfortunately curt) of Clark's collaborator Traube (I903), and Clark's own very brief discussion (1904, 62-3). The argument is accepted e.g. by Pasquali (1934) 8I and n. 3 (and subsequent editions).

I6 Robinson (1936); Seyfarth (1962) 8 and n. I with a supplementary argument discussed further below; Seyfarth (1978) vii; Reynolds (1983) 7. 
first made by Robinson point by point, and show that $\mathrm{V}$, in fact, cannot be a direct copy of $\mathrm{M}$ (section III); then we shall see what can be deduced about the archetype and the production of our two manuscripts (section Iv); and at last examine what conclusions arise from revising the theory of the two manuscripts' relationship (section v).

\section{The new fragments}

Since Robinson's case is based on the quality of the text in the six pages of M he knew, the discovery of the new fragments calls for a reappraisal of his argument. In publishing them, Broszinski and Teitler did not conduct such a reappraisal, in spite of the fact that they uncovered two more errors in $\mathrm{M}$ not in $\mathrm{V}$ in a passage of just eighty words in length.

\section{I8.6.13 per pabulum $\mathrm{V}]$ per rabulum $\mathrm{M}$}

I8.6.I5 lampade V] lampadae $M$

Lampadae, they claim with some justice, is a mere orthographic error. ${ }^{17}$ This is true, though it is indicative of a more elementary confusion than something like paenetrari for penetrari (30.3.3). Per rabulum is certainly contained in $\mathrm{M}$; what $\mathrm{V}$ originally read is harder to discern as there is later manipulation. Broszinski and Teitler follow Clark, who thought that V's original reading was rabulum. Clark, however, ignored the existence of an erased ascender on the first letter. It seems more likely that $\mathrm{V}$ originally contained babulum, as Eyssenhardt hesitantly suggested. ${ }^{\mathrm{I}}$ Still, the reading rabulum in $\mathrm{M}$ is revealing; it suggests that the archetype of $\mathrm{M}$ and $\mathrm{V}$ was in a script where $r$ and $p$ (and possibly $b$ ) could be confused.

Moreover, Broszinski and Teitler's transcription is capable of improvement. Thanks to the high-resolution facsimile made publicly available by the Universitätsbibliothek Kassel, we have been able to recover a number of letters that they were not able to see (see the Appendix below for a full transcription), and have identified one additional error in $M$ which they missed: I8.5.I calcitraret V] /trare M. As can be seen in the detail in Figure I, the $e$ is followed by a punctus and then the majuscule $f$ of flexus. Above the $e$ to the right, one can see a mark that could conceivably be Gelenius' insertion of a $t$ (compare for example his minute corrections in $\mathrm{M} 4 \mathrm{v}$, Il. I3-I4; see $\mathrm{n} .7$ above). It is certainly not a contemporary correction.

Adding this new error gives us three mistakes in $\mathrm{M}$ which are not in $\mathrm{V}$ in the new fragment, about one every twenty-five words. If we add these fragments to Robinson's assessment of those discovered earlier, the proportion of places where $\mathrm{V}$ has a better reading than $M$ rises from five in 55 to 8 in 58 ; instead of being ten times as accurate, $M$ is only six times more accurate than $\mathrm{V}$ (and we shall later see reasons to lower the multiple further). If the new fragment is more typical of $\mathrm{M}$ as a whole than the old,

I7 Broszinski and Teitler (I990) 423.

I8 Eyssenhardt (I87I) I33. 

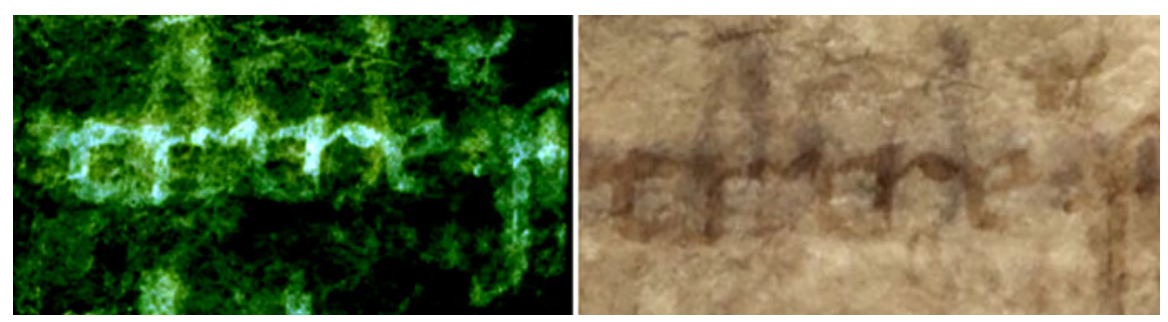

Figure I. M Ir, detail, with and without colour enhancement. University Library, Kassel, $4^{\circ}$ Ms. chem. 3 I.

$\mathrm{V}$ should have thousands of correct readings not in $\mathrm{M}$. Hence, what Robinson saw as the 'unbelievable accuracy' of $\mathrm{M}$ against $\mathrm{V}$ does not seem so certain: it might actually be a reflection of varying levels of competence among V's scribes. As it happens, the scribe of $\mathrm{V}$ for the passages in book 18 (the second scribe overall, whose contribution runs from I4.6.25 to I9.2.6) does seem to be the most consistently accurate, with comparatively few lines omitted and restored in the margin, and his distinctively spidery hand, easily distinguished from the many other scribes, reappears later correcting the work of his successors. At any rate, the impact of the new fragments should certainly make us examine the rest of Robinson's case more closely.

\section{Is $\mathrm{V}$ an apograph of $\mathrm{M}$ ?}

The case Robinson makes is twofold: after demonstrating the overwhelming evidence for M's textual superiority, he tries to show from $M$ that $V$ must have been directly copied from it, using the evidence of letter-forms, physical features and scribal practice. His arguments have subsequently been supplemented by Seyfarth. We demonstrate that a close examination of the evidence not only does not prove V's direct descent from M, but indeed disproves it.

\section{III.1 Lacunae}

Potentially the most compelling of Robinson's arguments is his claim that $\mathrm{V}$ omits lacunae that occur at the end of the line in M. Unfortunately, he could only come up with two examples, and one of these, at 28.4 .26 (4v, 1. 13 = R. xli) bos nouunt for bonum norunt, is so short, only two characters long, that it might not be a lacuna, as Robinson admits, ${ }^{\mathrm{I} 9}$ and even if it is, could, given its brevity, just as easily have been missed in the middle as at the end of a line. There are also lacunae at line-end in $\mathrm{M}$ which are likewise present in $\mathrm{V}$ (e.g. M 4r, l. II, after 28.4.23 licet and V, fol. I63V, l. 24). This leaves only one case, just

I9 Robinson (1936), I29 n. 53 . 
above in the same section 28.4.26 (M 4v, l. I2 = R. xxxvii) - and all this single example would signify is that $\mathrm{V}$ missed a lacuna in its archetype. The fact that it is at the end of the line in $\mathrm{M}$ could be mere coincidence. More troublingly, the reading adopted by both Clark and Seyfarth is a reconstruction by Heraeus, ancillas suapte natura pallidior spiritu, ${ }^{20}$ a reading that more closely follows $\mathrm{V}$, which has no lacuna between pallidi and aspirati, than M. Whether Heraeus' conjecture is correct is another matter (no continuous sense can be extracted from the passage), but there is no definitive evidence in favour of the lacuna. It can hardly be incidental that $\mathrm{V}$ omits a lacuna where the text possibly requires none. Indeed it seems equally possible that $M$ introduced a lacuna where the archetype had none. Further, there may be other lacunae in $\mathrm{M}$ which are not in $\mathrm{V}$; for example, in the last line of fol. $7 \mathrm{r}, \mathrm{M}$ has a space of about six letters after the punctus before the new period beginning Remigius (30.2.10), which is much longer than the space of one or two letters it usually leaves after a punctus. V, by contrast, leaves a space of only three characters (fol. I85r, 1. I9), as it usually does after a punctus. It looks like $\mathrm{M}$ has indicated a non-existent lacuna, not to be found in $\mathrm{V}$.

\section{III.2 Letter-forms}

Some of Robinson's remaining arguments rest on faulty analysis of the writing of $\mathrm{M}$. In 23.6.38 (R. i) usus] usus M usue V, Robinson (1936, I29) claims that there is 'a blot or some kind of blemish' on the s which makes it look like an e (M 3r, l. 4). In reality (as Robinson feared), it is a trick of black and white photography, where the writing on the reverse of the folio seems to bleed through under a flash, and becomes indistinguishable from the writing on the front. The colour facsimiles clearly show that the $s$ (an s-longa) looks exactly as it should, and $\mathrm{V}$ simply made an error, possibly due to confusion of letter-forms (in some scripts, $s$ can be confused with e), but only if $\mathrm{V}$ was not copied from M. In 30.2.8 (R. Ixxxviii), si ad ea, M reads sieadea (with a deletion mark under the first $e$ ) and V si eadea. Robinson (1936, 130) considers this the 'most convincing single bit of evidence we have'. The idea that the scribe of $\mathrm{V}$ mistook a deletion mark under an $e$ for an e-caudata is clever, but improbable. The mark in $M(M 7 r, 1$. I8) does not look like a cauda, but a punctus, separated as it is from the letter. Our eyes, which have been trained on the appearance of the printed page, might consider that a scant difference, but it would have been immediately apparent to a medieval scribe. Robinson does not consider the obvious solution: the archetype read sieadea (arising from a correction from si eadem to si ad ea - confusion of ad ea and eadem is very common). The superfluous $e$ was deleted by $\mathrm{M}$ (probably $\mathrm{M}^{\mathrm{a}}$ ) ex ope ingenii; $\mathrm{V}$, less ingeniosus by all accounts, hypercorrected it to e-caudata. Likewise, in 30.2.12 ( $M 7 \mathrm{~V}, 1$. I8 $=\mathrm{R}$. xcvii), the scribe of $M$ had dipped his pen before finishing off the $e$ in urgente; the result is not elegant, but it certainly does not look like an $x$. V's urgente is yet another hypercorrection. The shape of $\mathrm{rg}$ in $\mathbf{2 8 . 4 . 2 7}$

20 MV offer the words ancillas capte natura pallidi aspirati, $M$ with a punctus followed by a space of at least five characters after pallidi at the end of the line, $\mathrm{V}$ without lacuna. 
( $\mathrm{M}_{4}$ v, l. I8 = R. xlii) turgidos does not look like ng, nor does M's $x \mathrm{t}$ in 28.6.I (M 6v, 1. $2=$ R. Ixxviii) textus look like an at. In the latter case, a later crease in the parchment generates the illusion of an irregular letter-formation. Indeed, a for $x$ is an attested confusion, as for example in the manuscripts of Lucretius 3.596 exsangui] easangui and 6.385 extulerit] eatulerit (fa-). ${ }^{2 \mathrm{I}}$ In fact, exactly the same confusion is found a little earlier in both $\mathrm{M}$ and V, 28.4.26 fatorum] extoruith MV. Additionally, at the occurrence of the same word textus in 28.I.I7, V's $x$ is superimposed upon another letter, quite possibly an a. Hence, neither of these two examples gives any support to the idea that V's readings, tungidos and teatus respectively, were derived from aberrations in $M$. In a final case, at 30.3.2 (R. cii) gestorum, Robinson (1936, 130) finds what he calls 'a very striking bit of evidence', where M's supposed 0 looks like an $e$, thereby giving rise to V's gesterum. In fact, M's 0 is simply an $e(M 7 \mathrm{v}, 1.23)$, lacking the extended tongue, to be sure, but formed with a single stroke, unlike the double stroke of M's 0 . The te here is identical to the te found a line below in teme(rare). Hence, the archetype read gesterum. ${ }^{22}$ All of these examples show that Robinson's arguments from letter-forms in $M$ simply do not withstand close analysis, particularly with the aid of high-resolution colour facsimiles.

The rest of Robinson's arguments from letter-forms are simply ad hoc explanations of how particular corruptions could have arisen if $\mathrm{V}$ were copied from $\mathrm{M}$, without providing any proof at all that $\mathrm{V}$ was in fact copied from $\mathrm{M}$. Their probative value is nil, and since the archetype did in fact have the same text, and fairly similar line-length (see below), such explanations could fit the archetype just as well as $\mathrm{M}$.

\section{III.3 Punctuation and word-separation}

Punctuation and word-separation can be dealt with briefly. Since the pioneering studies of Parkes and Saenger, we have a much more nuanced and accurate understanding of their employment in Carolingian manuscripts. ${ }^{23}$ In ninth- and tenth-century manuscripts they depend on how the scribes literally read the text, that is, how they grouped together units of words, as they orally pronounced the lines they were writing. No evidence can therefore be gleaned from these areas to establish the priority of $\mathrm{M}$, and the new fragments offer cases where $\mathrm{M}$ divides and $\mathrm{V}$ does not (2v, 1. I4, in the Appendix below), and vice versa (2r, ll. 2, 9, and 15$)$.

\section{III.4 Stichometry}

Robinson's final argument rests upon stichometry, or the line-lengths in V's archetype and $\mathrm{M}$. We are in the unique position of having a very good idea of V's archetype's line-lengths,

2I See Merrill (1926) 43 and roo. Other cases may be found in Pliny the Elder, 29.72 auxilium] aua illum, 34.87 perixyomenon] perlayomenon and 35.174 in neapolitano] in expolitano. We thank one of CCJ's referees for pointing out these readings.

22 This reading (R. cii) should thus be subtracted from the total of 50 where Robinson saw M as superior to V.

23 Parkes (1993) and Saenger (1997). 
due to the negligence of V's scribes and the diligence with which it was corrected. For example, on fol. 92r, 1. Io (22.8.14), $\mathrm{V}$ has the nonsense admaxionem. But the corrector has deleted adma with deletion points, and supplied in the upper margin, $h[0 c$ est] ad mare ionium permeavit; dextrum igitur infle. What the corrector is telling us is that the original scribe skipped a line, i.e. the archetype read:

$$
\text { ad ma }
$$

re ionium permeavit; dextrum igitur infle xionem ...

Further evidence for line-lengths in $\mathrm{V}$ includes other marginal additions that have the same general length, but do not break up individual words. Finally, we also have the evidence of Gelenius' edition, in which he supplied (as Froben tells us) 'whole lines' which were missing in $\mathrm{V}$ from the Hersfeldensis. ${ }^{24}$ Taking all these categories together Robinson gathers 59 examples of lines from V's archetype, falling within the range of 35 to 49 characters per line, with an average of 42 . Likewise, he counts the number of characters in the lines from the extant fragments of $M$, and finds 264 lines, with an average of 46 characters. That, according to Robinson, is close enough to assert the identity of $M$ with the archetype of $\mathrm{V}$, considering how small a sample from the whole we have access to. ${ }^{25}$

With the important exception of this final assertion, we have no quarrel with Robinson's methodology. He was meticulous in taking account of erasures in the main text as well as marginal lines to work out the precise length of lines of the archetype preserved in V's margins. He was also prudent in excluding some omissions restored in the margins that were anomalous, mostly shorter ones that could be explained as cases of saut du même au même, ${ }^{26}$ and likewise in distinguishing between omissions that broke up words and those that did not, though in practice the range and average length of the reconstructed lines prove to be virtually identical. After checking his work, adding a line from $\mathrm{M}$ and another line from the margins of $\mathrm{V}$ that he missed, and a further three cases where transpositions in the text, corrected by the scribes, can clearly be seen as the result of skipping a line, we reached a very similar result to his. ${ }^{27}$ From 64 lines we found the same range of 35 to 49 letters and calculated an average length for lines in the archetype of $\mathrm{V}$ of $4 \mathrm{I} .8$. Of

24 See n. 3 above.

25 Robinson (1936) $136-9$.

26 E.g. at I7.II.I, where a 57-character marginal passage is also found accurately in the text; at 2I.9.5, 22.I5.3, 30.8.II, he left out of consideration passages of 30 letters or under, all explicable as saut du même au même. He also discounted two longer passages (I6.9.3, II6 characters; 20.3.9, I90 characters).

27 The omitted line restored by Gelenius is at 22.I.2-3 (43 characters). The omitted marginal line from $V$ is at 22.I2.6: sua diuersa oria [i.e. diuersoria] portarentur petulantes ante. The three other cases are (a) 2I.I.2, where the scribe skipped from the word alliceret to the word prior, supplying later in the sentence the omitted words in concordiam an terroris incutiendi gratia lacesseret, and using supralinear marks to indicate the transposition ( 48 characters: obviously a case of saut du même au même, but easier if the two similar words were at the end of a line); (b) 21.2.20, where in similar fashion -ebus exploratiuos [i.e. exploratius] spectato negotium Mamertino was at first omitted, the initial di- of diebus was joined to the tum a line down which was read as dirum (4I characters); (c) 22.4.6, where the scribe appears to start 
course some of these omissions may have occurred in other ways than a single line of text being omitted, not only the obvious saut du même au même but also the copyist's eye dropping a line in the middle of the page. Reassuring, however, is the fact that, if cases where même au même is a likely explanation are excluded, the average line-length of our sample is virtually identical. ${ }^{28}$ Likewise, if we consider only cases where the omission of a line included breaking up a word - and therefore almost certainly a product of line-omission - it produces a similar range of 35 to 46 and a very similar mean line-length of $4 \mathrm{I} .5$ letters. ${ }^{29}$

In the case of $\mathrm{M}$, we can add line-lengths from the newly discovered passages: these are reconstructed, in that the lines are only partial, but it is clear that the missing text can vary only minimally in length from that preserved in V. Adding $3^{8}$ lines, we reach a total of 304 extant or reconstructable lines of $M$ with an average length of 46.2 letters, with a range from 35 to $56 .^{30}$ It would, of course, be possible to calculate the length of lines of $M$ on the basis of the amount of text on all known or reconstructable pages: one could add text lost in between closely positioned fragments, not only between $\mathrm{Ir}$ and $\mathrm{IV}, 2 \mathrm{r}$ and $2 \mathrm{v}$, and $5 \mathrm{r}$ and $5 \mathrm{v}$, but also the complete missing bifolium between fols. I and 2, and the missing folio between fols. 5 and 6 . Factoring in those pages would give an average number of letters per page of I,094 and of just over 45.5 characters per line. ${ }^{3 \mathrm{I}}$ However, since we do not ultimately know what was or was not in those lost folios, it seems best to stick to a calculation based on lines actually preserved or closely reconstructable.

Where Robinson went wrong, however, was in his impressionistic response to the results of his survey on line-lengths: that averages of 42 and 46 were close enough. The sort of problem we have here requires a relatively straightforward statistical procedure. We have two samples - the lines from V's archetype and the lines in the extant fragments of $\mathrm{M}$ - and we want to determine whether those two samples come from the same population, that is, whether V's archetype is statistically identical to $M$ in linelength. The classic formula is Student's t-test, since it is reasonable to assume that the line-lengths in a manuscript would follow a normal distribution ( $M$, unlike $V$, seems to be written in a single hand throughout) and the t-test has been shown to be fairly robust

copying the same line he has just copied (sit uideri subiecto adeo autem ferox erat in suos illius, before deleting it again: 47 characters). There may be other such passages that we have yet to identify.

28 4I.76 against 4I.78 letters per line.

29 A suggestive confirmation that we are indeed dealing with whole lines, rather than other sorts of omission, comes from comparing marginal lines in a Fulda manuscript roughly contemporary with V, Bamberg Msc. Class. 54 of the Historia Augusta, for which we possess the exemplar, Vatican City, Pal. Lat. 889. Eight snatches of text are supplied in the margin of the Bambergensis (28v, 39v, 74v, 92r, I02v, I05v, IIOv, I94v), and all but one of them arise from omission of a complete line in Pal. Lat. 889: the exception, on ro5v, caused by a saut du même au même, would have been excluded in the methodology followed here for being significantly longer than the rest.

30 In this measurement lines with gaps marking lacunae are excluded from the count. However, where part of a line is missing but the text can be supplied from V (as in fols. I, 2 and 7), the reconstructed lines are counted. In no case does this lead to reconstructed lines of a length outside the known range.

3I Page lengths are (* indicates some degree of reconstruction): Ir I,IOO*; IV and four additional intervening sides

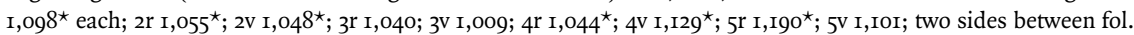
5 and fol. 6, I,III* each; 6r I,I93; 6v I,I65; 7r I,055* (NB only 23 lines); 7V I,IOO; 8r I,020; 8v I,II8. 
even in non-standard populations. ${ }^{32}$ Further, we have relatively random samples: the lines of V's archetype are from throughout the text, and the fragments of $\mathrm{M}$, including the new ones, are from four different books, which means that progressive variation throughout the codex should not affect our sampling. The randomness of our samples more than compensates for the small proportion of the whole they represent. The t-test is used to calculate the probability of a null hypothesis that two samples represent the same population; if the $t$ value exceeds a certain threshold, we reject the null hypothesis. So in this case, our two populations are the line-lengths of $\mathrm{M}$ and the line-lengths of V's archetype, and the null hypothesis is that of Robinson, that they represent the same population, i.e. that M is V's archetype. For our test, the number of samples in our first set (lines in the fragments of $M$, including the new fragments) is $302\left(\mathrm{n}_{\mathrm{a}}=302\right)$, and in our second (lines from V's archetype $)$ it is $56\left(n_{b}=56\right)$. Performing a $t$-test $(t=8.367 ; p$ [robability]<.oor two tailed $)$ shows that it is extremely unlikely that the two samples derive from the same population.

But the t-test assumes normal distribution - which is a reasonable assumption, but one that has never been demonstrated for characters per line in a manuscript. Hence, we can also use a Wilcoxon rank-sum test, which determines the same thing, but does not make any strong assumptions about the distribution of the population. ${ }^{33}$ Like a t-test, however, the Wilcoxon rank-sum test tests the null hypothesis that the two samples come from the same population. It returns a $\mathrm{W}$ value, which is used to reject the null hypothesis if it exceeds a set value. For this text, our sample numbers are the same $\left(n_{a}=302\right.$ and $n_{b}=$ 56), while the median values are 45.5 for $n_{a}$ and $4 \mathrm{I}$.o for $n_{b}$. Running the test shows us that the two groups differ significantly $(\mathrm{W}=\mathrm{I} 384 \mathrm{I}, \mathrm{p}<$.0oI two tailed). So we can reject the null hypothesis that the two samples come from the same population with more than $99 \%$ certainty; the chance that the lines from V's archetype were originally in the Hersfeldensis is less than one tenth of I per cent. Hence, the stichometric arguments that Robinson found persuasive not only are not as sound as he believed but actually very strongly indicate the opposite, that $\mathrm{V}$ was not copied from $\mathrm{M}$.

\section{III.5 Length of gatherings}

At this point, one related argument, not adduced by Robinson, but in his support, needs to be confronted. Wolfgang Seyfarth, later to edit Ammianus, argued in 1962 that conclusive support for V's dependence on M could be found in an oddity of book 29. In that book, two lengthy passages of text have been transmitted the wrong way round in the Vaticanus: the order is 29.I.I-I7, 29.3.4-29.5.39, 29.I.I7-29.3.4, 29.5.39-end. This is a mechanical error caused by two quaternions being bound in the wrong order at an earlier stage of transmission. If one starts from the assumption that that earlier stage was the Hersfeldensis, the fact that Gelenius was first to correct the mistake may look like

32 Any standard handbook of statistics will describe Student's t test; an accessible overview can be found in the Encyclopedia Brittanica Online, s.v. 'Student's t test' (http://www.britannica.com/science/Students-t-test). 
confirmation: but in fact, the problem should not have been beyond a good scholar and it is rather more surprising that it was not already solved by Mariangelus Accursius, who published his edition, containing the editio princeps of books 27-31, a few months earlier than Gelenius in 1533. Seyfarth's argument is rather more sophisticated. He calculates that the length of the reversed passages is almost exactly what one would expect for a quaternion of the Hersfeldensis, which should have 17,664 letters. His estimate is that the putative quaternion 29.1.17-29.3.4 contains 17,690 characters. The calculation is harder for the second quaternion, 29.3.4-29.5.39, given the regular series of three-line lacunae that punctuate it at beginning and end, but Seyfarth allows I,242 characters (27 lines of the Hersfeldensis) for the lacunae and subtracts to reach a figure of 16,422 characters as target length for the remaining text, which is then matched by his estimate of 16,356 characters. ${ }^{34}$

There are two problems with this reasoning. First, his calculation of the length of the quaternions, carried out by counting lines in Clark's edition and multiplying by an estimated average, is slightly awry: 29.1.17-29.3.4 is in fact not 17,690 but 18,220 characters, which would imply an average of I,I40 characters per side, within the range of known pages of the Hersfeldensis but markedly higher than the average. ${ }^{35}$ Given the good reasons we have adduced to calculate that the archetype of $\mathrm{V}$ had an average of 42 characters per line, it seems likely that we should in fact imagine a manuscript with slightly shorter lines than the Hersfeldensis but rather more lines per page: probably 27 rather than 24. Seyfarth's calculation merely shows that the archetype had pages of a similar length to M's, if perhaps slightly longer.

\section{III.6 A curious error in $\mathrm{V}$}

Further evidence for the format of the exemplar of $\mathrm{V}$ can be gleaned from comparing $\mathrm{V}$ with the new fragments of M. V has a curious mistake in book Ig: it comes a page after a new scribe has taken over, aptly described in Clark's apparatus (I9.2.6) as scriba multo neglegentior. After miscopying the first syllable of the word pallente (19.2.I4, bal-), the scribe suddenly starts, at fol. 59r, 1. I4, to copy a passage from the previous book, 18.6.20-2 (Syriis-mente quadam). The passage is copied haphazardly for twelve lines before suddenly the scribe stops and starts again on the word, pallente, that he should have been copying at the start. The repetition in $\mathrm{V}$ is not deleted, with the result that several of its descendants copied the repeated passage and it even appeared in the first four printed editions, before being removed by Accursius and Gelenius. In what circumstances could such a bizarre error have occurred? The most plausible explanation would seem to be that the scribe stopped at the end of a page, and having not properly marked the place

34 Seyfarth (1962) $8 \mathrm{n}$. I.

35 This calculation was made on the basis of electronically counting letters in a transcription of $\mathrm{V}$, expanding abbreviations to accord with the practice of $\mathrm{M}$ but counting \& as one letter, and including punctuation only if found in $\mathrm{V}$ itself. We deliberately leave the second quaternion out of account, since lacunae make counting its original length a circular calculation. 
returned after a pause to open the exemplar, or find the exemplar open, at what was in fact the wrong page. If the exemplar was unbound - and perhaps this is likelier - the scribe may have reached the end of a quaternion and then resumed copying the start of the same gathering rather than the next one; the 17,400 characters' distance between the two passages is in fact close to the length of the two gatherings in book 29 that we have seen were misplaced at some point in transmission..$^{36}$

One result of the discovery of the new fragments of $M$ from book 18 is that we can calculate where in $\mathrm{M}$ I8.6.20-2 stood: it would have been about two thirds of the way down the seventh folio, recto, of a quaternion. If it had been at the top of a page or, even more, at the start of a quaternion, it might have acted as a powerful argument in support of V's derivation from M. Conversely, the actual situation implies that V is probably not a copy of $\mathrm{M}$. Of course, it cannot be ruled out that the dislocation happened at an earlier stage in the transmission, but the fact that this error coincides with a change in scribe in $\mathrm{V}$, who would not have recognised the text from the earlier book, and who at any rate is markedly unreliable, strongly suggests that its genesis is in V itself.

The case for $\mathrm{V}$ being an apograph of $\mathrm{M}$ does not stand up to close scrutiny. Robinson and Seyfarth have compiled an impressive number of different and independent pieces of evidence, but none of them withstands detailed analysis and one of them - the stichometry - virtually proves the opposite, that V was not directly copied from $\mathrm{M}$.

\section{Evidence for a shared archetype}

The evidence indicates that V was not copied directly from M. By itself, this fact does not prove that $\mathrm{M}$ and $\mathrm{V}$ are both copies of a single archetype, although some of the features we have examined seem to point in that direction, since, as we noted above, there remains the theoretical possibility that $\mathrm{V}$ was copied indirectly from $\mathrm{M}$, that is, through one or more intermediaries. In the section, we will examine the positive evidence that $M$ and $\mathrm{V}$ were both copied from a common archetype.

\section{IV.1 Palaeographical evidence}

Robinson, in searching for cases in which errors in $\mathrm{V}$ could be explained palaeographically from $\mathrm{M}$, overlooked the more compelling palaeographic evidence that $\mathrm{M}$ and $\mathrm{V}$ share a common archetype. In fact, we have already seen in section III.2 above one case where M and $\mathrm{V}$ seem to display parallel confusion ( $a$ for $x$ ). More examples may be added:

28.5.I (R. lviii) intento] intento $M$ invento $V$

30.3.2 (R. ci) moxque veris] /que veveris $M$ moxque veteris $\mathrm{V}$

36 Above, section iii.5. The lengths will be still closer if one allows for the space taken up by the heading of book 19 , quite plausibly on a fresh page. 
$\mathrm{V}$ commits a similar error in both these cases (in the latter case, the iterated ve is probably archetypal). In the first, $\mathrm{V}$ reads te as ve, and in the second ve as te. This suggests that the archetype of $\mathrm{V}$ was in a script in which ve and te were liable to confusion. Insular script provides the most obvious solution, with its characteristically fine crossbar on the $t$, and the rounded first stroke common to both $t$ and $v .{ }^{37}$ Were the script fairly compressed, it would be easy to see the rounded first stroke of the $e$ as the second stroke of a $v$.

It is also clear from Robinson's collation that $\mathrm{V}$ frequently confuses $a$ for 0 and (more rarely) o for $a$ :

\subsubsection{0 (R. ix) abolito] abolito M obolito V \\ 28.4.26 (R. xxxviii) consumpto] consumpto $M$ consumpta $V$ \\ 30.4.I (R. cxix) navabatur] navabatur $M$ novabatur $\mathrm{V}$ \\ 30.4.2 (R. cxxv) imperiale] imperiale $M\left(M^{a}\right.$ ?) imperiole $V$}

Insular script, and other scripts with a full round $a$, offer a convincing explanation for this error. But this error would not have consistently arisen from the Caroline $a$ of $\mathrm{M}$, with its small, frequently open and sometimes almost imperceptible loop. Rather, we know that this error derives from the script of the archetype, because on two occasions $\mathrm{V}$ gets it right and $M$ gets it wrong, and in several further instances both $M$ and $V$ misread an $a$ for 0 or vice versa:

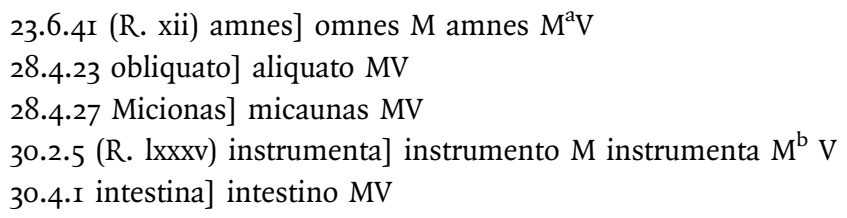

The same can be said of the error in the new fragment I8.6.I3 per pabulum V] per rabulum M. ${ }^{38}$ The potential for confusion between $p$ and $r$ is known to be a symptom of the archetype. Whatever $\mathrm{V}$ originally read, $\mathrm{M}$ certainly saw an $r$ where there should be a $\mathrm{p}$.

The fact that here we have $\mathrm{M}$ making this error probably independently of $\mathrm{V}$ shows that $\mathrm{V}$ was copied from the archetype not from $M$.

Perhaps even more significant is V's error in 28.5.II (R. lxvii) ne nuda] Nenuda M renuda V. Confusion of $n$ for $r$ is one of the most common of all errors in minuscule, but here $M$ uses the majuscule form $\mathrm{N} . \mathrm{V}$ is certainly capable of gross misreading, but it seems very suspicious that the scribe just happened to make an inexplicable slip in precisely a context where we might expect a simple palaeographic mistake. Taken together with

37 Traube (1903) was the first to propose an insular stage in the transmission of Ammianus; that proposal has survived the rigorous interrogation of Dumville (1995) 2II-I2, who adds that it was probably a continental Anglo-Saxon insular script.

$3^{8}$ See section ii above. 
Robinson's other examples of letter confusion (R. xlii, ng for $\mathrm{rg}$ and R. lxxviii, at for xt, discussed above) which do not seem to have an origin in the script of $M$, these cases suggest that many of V's errors can be explained palaeographically, but only if its archetype is not $\mathrm{M}$.

\section{IV.2 Multiple hands around lacunae}

Further, close examination of $\mathrm{V}$ indicates that at some points there are clear variations in the writing around the lacunae. This is most evident on fol. I75, both on the verso and the recto, where the writing is clearly different around the two long lacunae. ${ }^{39}$ On $175 \mathrm{v}$, the main scribe left a large gap of at least seven lines. Subsequently, that scribe or another returned to the passage and copied parts of four of the missing lines. Such a practice would be very difficult to account for if the archetype was a manuscript like $M$ with the lacunae already indicated; if, however, the archetype was physically damaged, it would make perfect sense for the scribe to have had recourse to a more experienced colleague, or to have returned later to the same passage to see what more could be deciphered. If $M$ were V's archetype, it must have suffered additional physical damage in what would necessarily, on palaeographical grounds, have been the very brief period between its writing and V's.

\section{IV.3 Correcting hands in $M$}

If $\mathrm{V}$ were copied from $\mathrm{M}$, it must have been copied after the first corrector $\left(\mathrm{M}^{\mathrm{a}}\right)$ was at work, as attested by the following:

23.6.4I ( $M$ 3r, l. 34=R. xii): amnes] omnes $M$ amnes $M^{\mathrm{a} V}$

23.6.43 (M 3V, ll. IO-II = R. Xvi): Artacana] arteana $M$ artacana $M^{\mathrm{a}} \mathrm{V}$

28.5.2 ( $M$ 5v, l. I4 = R. lix): cum milites] conmilites $M$ cum milites $M^{\mathrm{a} V}$

30.2.II ( $M 7 \mathrm{v}, 1.5=\mathrm{R}$. xci): praefectus] praefectos $M$ praefectus $M^{\mathrm{a} V}$

$\left(\mathrm{M} 7 \mathrm{v}, 1.6=\mathrm{R}\right.$. xcii): luis] ruis $M$ luis $\mathrm{M}^{\mathrm{a}} \mathrm{V}$

30.3.4 (M 8r, l. $\mathrm{I} 6=\mathrm{R}$. cxiii): quantoque] quante quae $M$ quanto quae $M^{\mathrm{a}} V$

30.3.5 (M 8r, 1. $22=$ R. cxvi): tutius] tutius $M$ totius $M^{\mathrm{a} V}$

Now this corrector is not identical to the main scribe. For example, in $M$ 4r, l. 6 (28.4.22), the corrector inserts another $i$ over the ii in regiis. Surely he did not think that the correct reading is regiiis; rather, as Robinson suggests, he read the word as regns, which clearly needs an $i$. This misunderstanding of the text points to a certain distance between the corrector and the main scribe: the difference between $i i$ and $n$ is perfectly clear in $M$, since the way they are written is very different, with a prominent curve at the top in the $n$. As Caroline minuscule matured, however, the forms of $i \mathfrak{i}, \mathfrak{n}$ and $u$ became increasingly assimilated, leading ultimately to the distinction of $i$ with a stroke.

39 The same can be seen in lacunae in the Historia Augusta, Pal. Lat. I54r-154v and Bamberg, Msc. Class. 54, fol. I53r, at the beginning of the lives of the Gallieni duo. On these manuscripts see also n. 29 above. 
That creates a palaeographical problem. As mentioned above, $\mathrm{V}$ is relatively securely placed by Bischoff around the year 830, while $M$ is placed nebulously in the first half of the ninth century. ${ }^{4^{\circ}}$ Palaeographers seem to agree that the two manuscripts were written close together, separated by no more than a couple of decades. The date of the writing of $\mathrm{M}$, however, is actually itself irrelevant to that of $\mathrm{V}$, since, on this theory, $\mathrm{V}$ could only have been written after $M$ was corrected. Therefore, the date of the first corrector $\left(M^{a}\right)$ is the relevant point, not the date of the main hand. The letter-forms of $\mathrm{M}^{\mathrm{a}}$ suggest a date somewhat later, no earlier than the middle of the ninth century. In two places above (28.5.2 and 30.2.II = R. lix and xci), $M^{a}$ has supplied a $u$. But the shape of his $u$ is not the earlier wide and rounded $u$ found in $\mathrm{M}$ and $\mathrm{V}$, but verging on the later two-minim style, where there are two descenders faintly joined by clubbing at the bottom (Figure 2).

This finding is consistent with the case discussed above (regiis at 27.4.22), where the corrector misread the main text of $\mathrm{M}$ in precisely this way. Judgements of this sort are of course subjective, and we ought not rely too much on such fine-grained palaeographical analysis. Nonetheless, the fact that $\mathrm{V}$ could only have been copied from $\mathrm{M}$ after correction makes an already tight chronology less probable. Even if it is just barely possible in palaeographical terms that $\mathrm{M}$ was written before 830 , it beggars belief to suggest that it was also corrected before that date. A fortiori the notion that $\mathrm{M}$ was written, corrected and copied, and that that copy in turn begat $\mathrm{V}$, is chronologically preposterous.

But, if $\mathrm{V}$ is not a descendant of $\mathrm{M}$, how do we explain the close agreement between $\mathrm{M}^{\mathrm{a}}$ and $\mathrm{V}$ ? The obvious answer is separate dependence on the archetype, but several pieces of evidence militate against this conclusion. An interesting case can be found at 30.4.I (M 8v, 1. Io = R. cxx): arctoum] areto um $M$ aroto um $M^{a}$ utroto um V. The scribe of $M$ made a simple slip of $e$ for $c$, while the scribe of V seriously misread his archetype's arc as utro (the correct reading is transmitted by V's corrector). Nonsense that may be, but at least it contains a recognisably Latin word, utro, which is more than can be said of M's reading. $\mathrm{M}^{\mathrm{a}}$, however, changes one bit of nonsense into another by replacing the $e$ with an 0 . Robinson thereby concludes (with some hesitation) that $\mathrm{V}$ must have been copied from $\mathrm{M}$ after its correction. But then where does $\mathrm{M}^{\mathrm{a}}$ 's 0 come from? Robinson suggests rather wildly that the archetype must have had so ill-formed a $c$ that the scribe first read $e$ and then changed his mind and made it an 0 . In any number of scripts, $c$ can be mistaken for $e$ and $c$ can be mistaken for 0 , but it is unlikely that a single $c$ could be mistaken for both. Rather, as elsewhere, $\mathrm{M}^{\mathrm{a}}$ for whatever reason has imported its o from V. Hence, this case is very much like 30.3.5 (M 8r, $1.22=\mathrm{R}$. cxvi) tutius, where $\mathrm{M}^{\mathrm{a}}$ replaced a good reading in $M$ with an error from $V$. The same can probably be said of 28.6.5 (M 6v, 1. 23 $=\mathrm{R}$. Ixxxiii) ducens $\mathrm{M}$, duces $\mathrm{V}$. The correct reading is ducens, and that is what $\mathrm{M}$ seems to have contained, albeit with an untypical ns ligature perhaps occasioned by the line end. Unreported by Robinson and the editions is $\mathrm{M}^{\mathrm{a}}$ s deletion mark under the first bar of the 


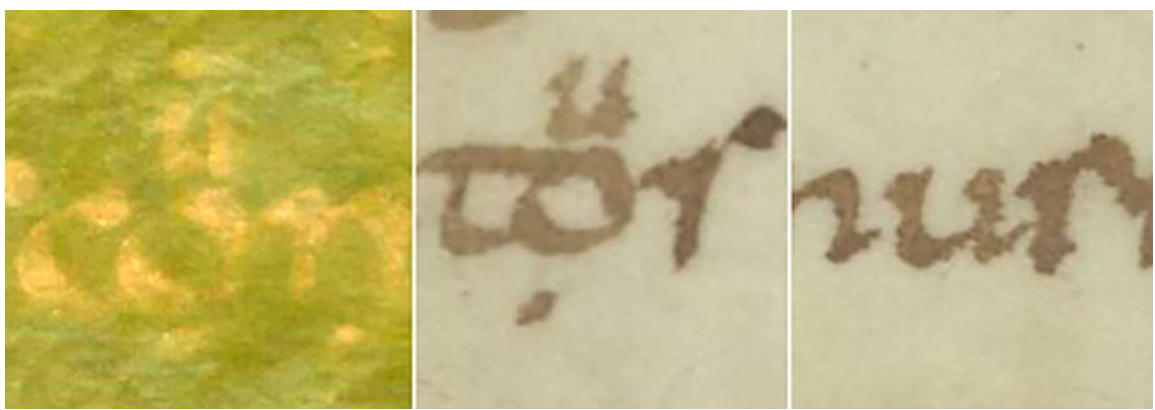

Figure 2. $M 5 v$ (colour enhanced) and $M 7 v$, details of $M^{a}$ s $u$ and $M$ 's next $u$ in the same line. University Library, Kassel, $2^{\circ}$ Ms. philol. 27.

$\mathrm{N}$; he also seems to have overwritten the $s$ of the ligature with another, clearer $\mathrm{s}$. This suggests unavoidably that $\mathrm{M}^{\mathrm{a}}$ reads duces, the same erroneous reading found in V. Hence, all the evidence comes together to suggest that $\mathrm{M}$ was corrected from $\mathrm{V}$ - intelligently on the whole, but with a few tell-tale cases of imported corruption. In addition, four of the seven agreements between $M^{a}$ and $V$ against $M$ (three of them true) occur in the same passage (30.2.II-30.3.5); three of the five errors in $M$ that are not in $V$ are found in the same passage. This clustering suggests very strongly that the scribe of $M$ was not working to his normal standards as he copied those two folios, and his contribution is only a little more accurate than that of the scribe of $\mathrm{V}$ at this point. ${ }^{4 \mathrm{I}}$

There exist, however, a residue of instances where $\mathrm{M}^{\mathrm{a}}$ provides readings not in $\mathrm{V}$. They are not as numerous as Robinson supposed, but still present a potential obstacle to the argument that $\mathrm{M}$ was corrected from $\mathrm{V}$ :

28.4.22 (R. xxiv) regiis] regiis $M V$ regnis $M^{a}$

28.4.25 (R. xxxii) nec ante] negante MV necante $M^{a}$

28.4.26 (R. xxxv) profusius] profusus MV profusius $M^{a}$

28.6.4 (R. lxxxii) referti] reverti MV recerti $M^{a}$

30.2.Io (R. xc) favisse] fuisse MV favisse $M^{\mathrm{a}}$

Of these five readings, one turns truth in MV to error, another exchanges one error for another, and three are probably correct. It does not seem inappropriate to ascribe such a record to the talent of the corrector. His successful guesses are hardly brilliant, but they do show an awareness of grammatical problems in corrupt passages. Hence, the

4I This scribe's contribution parallels folios 4 to 8 of $M$ in books 28 and 30. This scribe displays a shifting ductus litterarum and is much less accurate than some of his fellows, in particular the second scribe, whose work is superior to that of $\mathrm{M}$ in the new fragments. But he is also not the worst scribe at work in the codex: that crown certainly belongs to the third scribe, who starts at 19.2.6, discussed in III.6 above. 
existence of non- $\mathrm{V}$ corrections by $\mathrm{M}^{\mathrm{a}}$ does not preclude the hypothesis that he had $\mathrm{V}$ at his disposal. Instead, the fact that there are vanishingly few correct $\mathrm{V}$ readings not imported into $\mathrm{M}$ by $\mathrm{M}^{\mathrm{a}}$ makes it very likely that $\mathrm{V}$ is the origin of $\mathrm{M}^{\mathrm{a}}$ 's readings.

This conclusion is important for gauging the relationship between the two manuscripts. If $\mathrm{M}$ was corrected from $\mathrm{V}$, then $\mathrm{V}$ has preserved many more correct readings than has been credited to it and $M$ does not quite deserve the plaudits it has received. $M$ still offers a vastly superior text to V: even when we add to V's credit the places where the corrector of M found the right answer in $\mathrm{V}$ (and to M's one where the corrector removed the correct reading), we still have only I4 places where $V$ has a correct reading not in $M$, as against 49 places where $M$ has the superior reading. However, the overall accuracy of $M$ is enhanced thanks to the diligence of its corrector, since it also transmits the majority of V's best readings as well.

\section{Editing Ammianus}

Gehen wir von den kleinen Stücken aus, die sowohl im Vaticanus (V) als in den Marburger Fragmenten (M) erhalten sind, so zeigen zunächst die Lesarten deutlich, daß weder $\mathrm{M}$ aus $\mathrm{V}$, noch $\mathrm{V}$ aus $\mathrm{M}$ abgeschrieben ist, sondern beide Handschriften derselben Vorlage (y) folgen..$^{42}$

So Ludwig Traube in I903. In this article we have taken issue with the view of Rodney P. Robinson on the relationship of the Hersfeldensis and Fuldensis of Ammianus, generally accepted since 1936; both by refuting Robinson's arguments and by adducing new ones, we have shown that the two manuscripts should be seen as gemelli, copies of the same parent. We shall have something to say about that parent and about the history of the Hersfeldensis elsewhere; but in this conclusion it will be useful to consider what differences our results make to the study of Ammianus and of the history of texts.

First, an important consequence of this reassessment is that the dating of the two manuscripts is no longer constrained by the requirement, somewhat against the instincts of palaeographers, that $\mathrm{M}$ predate $\mathrm{V}$. The date of the hand of $\mathrm{M}$ (and of its corrections) can now be revisited as a wholly palaeographical question.

What difference should it make to editions of Ammianus? Not a great deal. In purely presentational terms, the fact that $M$ does not constitute the archetype means that when both manuscripts are extant the apparatus ought to include the readings of both whenever they diverge, something which Seyfarth does not always do. ${ }^{43}$ In passages where $M$ is extant, it retains its status as the more reliable manuscript, even though not the archetype; but in almost all divergences between the two, that does not affect our

42 Traube (1903) 444, quoted also in Robinson (1936) I28 n. 52.

43 For example, at 28.4.26 Seyfarth prints the readings of $M$, which for him is the archetype, and gives only the readings of $\mathrm{V}$ (which he judges erroneous) in the apparatus. An editor should include both authoritative manuscripts: cultis MG, cultis et VEA; et Trulla MG, et contrulla V, et cum Trulla EA. 
judgement in practice. In most of the work, where M is not extant, the effect on the text is still more limited. Logically, our reassessment has the consequence that readings of $M$ preserved in Gelenius are not necessarily the readings of the archetype. The problem is, however, that, with few exceptions, the readings of Gelenius that differ from $\mathrm{V}$ cannot be demonstrated to represent those of $\mathrm{M},{ }^{44}$ and even in the exceptional cases (restored lines of the archetype or the entire Greek text of the obelisk inscription), Gelenius' tendency to bold emendation needs to be taken into account. We can and should note where readings are taken from an earlier edition, and are therefore less likely to represent $M$, and we can often identify Gelenius' own emendations from prose rhythm, since Gelenius was either unaware of the cursus or unaware of its regularity. ${ }^{45}$ The truth is, however, that on the vast majority of occasions when the readings of Gelenius are accepted it is because of their superiority rather than because of their source.

Nevertheless, a better understanding of the archetype and of the likely types of corruption does have the potential to improve our texts of Ammianus. One important area is lacunae, where we can now presume that the lacunae indicated in $\mathrm{V}$ are the scribes' attempts to represent what they saw in a damaged archetype, and that they are not filtered through another manuscript. ${ }^{46}$ In cases such as 28.4 .26 , where $M$ has a lacuna and V does not (discussed in section III.I above), we can choose which to believe.

Although the editorial gains are limited, this argument does touch upon questions and fields broader than the relationship of the two manuscripts to which we owe the preservation of Ammianus. That the exemplar of the Res gestae was copied twice within several decades in a very limited geographic area is striking. Producing even one such copy would have required a significant investment of resources - both in time and in materials - given the length of even the extant portion of the Res gestae; producing two indicates a very serious commitment to the study of Roman history. In fact, many late antique histories were transmitted in the milieu of Fulda and Hersfeld in the first half of the ninth century: the so-called Epitome de Caesaribus, the Historia Augusta, possibly Suetonius, the first six books of the Annales and the opera minora of Tacitus, to name a few. ${ }^{47}$ Elucidating the relationship between the two manuscripts of Ammianus - and particularly the fact that one manuscript was used to correct the other - sheds further light on this scholarly and scribal milieu. Further, the methods we have employed to arrive at these conclusions will, we hope, be of use in the study of other textual traditions.

44 However, when Gelenius' readings are (a) the same as or very similar to those of V, (b) different from those of the previous printed editions, and (c) impossible to conjecture on the basis of those editions, we can identify his use of the Hersfeldensis.

45 The fundamental points on the apparatus are already in Mommsen (1872); on Gelenius in Harmon (I9I0) 234-5.

46 Cf. Stover (forthcoming b).

47 See the list in McKitterick (2004), table 9.I. On the relationship of scribal practices in the transmission of the Epitome and Ammianus see Stover (forthcoming a). 


\section{Appendix}

\section{Diplomatic edition of the new fragments of $M$}

Thanks to the high-resolution colour facsimiles made available online by the Universitätsbibliothek Kassel, we have been able to discern more of the text in some places than Broszinski and Teitler (1990); in others, we were not confident that what they printed was actually visible. In one place, as explained above (section II), we disagree with their reading.

The text not in bold, a corrected version of $\mathrm{V}$, is purely indicative of characters wholly irrecoverable because of abrasion, trimming or physical damage. The text of the fragment is printed in bold. Individual letters are printed when enough survives to distinguish them; those that can be seen but not securely identified are italicised.

M Ir (I8.5.I)

I trare. Flexus in blanditias molliores confessusque

2 debitum per conludia in nomen fisci translatum iam

3 queausurus inmania

I -traret $V$, edd., trare $M$; a small mark above and right of the $e$ could possibly represent a t; if so it is in a second hand, and could represent correction in Gelenius' hand; cf. M 4v, 11 . I3-I4.

M Iv (I8.5.3)

Tamsapore habitis I

qui tractus omnes aduersos ducis potestate tunctueba 2

tur \& antea cognitus misso a Persicis castris auxilio 3

M 2r (I8.6.12-15)

I hensum. Cum ego rapido ictu transirem interrogassent

2 quisnamprofectus sit iudex audissentque Ursicinum pau

3 loante urbem ingressum montem Izalam petere occiso in

4 dice in unum quaesiti conplures nos inrequietis cur

5 sibus sectabantur quos cum iumenti agilitate prae

6 gressus apudamudin munimentum infirmum disper

7 sis perrabulum equis recubantes nos securius in

8 uenissem porrecto extentius brachio et summitatibus

9 sagicontortis elatius adesse hostes signo solito demon

Io strabam Isdemque iunctus impetu communi ferebar

II aequo iam fatiscente terrebat autem nos plenilunium

I2 Noctis \& planities supina camporum nulla si occupas

I3 s\& artior casus latibula praebere sufficiens ubi nec arbo 
I4 res Nec frutecta nec quicquam praeter herbas humi

I5 lesuisebatur. Excogitatum est ergo ut ardente superpo

I6 sita lampadae \& circumligata ne rueret iumentum

I7 solum quodeam uehebat solutum sine rectore leuors

I8 us ire permitteretur

2 quisna[m] p[ro]fectus $V$, prouectus Valesius, edd. 4 Line almost lost due to the cutting of the folio. 5 -bant [ur] V 7 per pabulum V, edd. In Clark's view, V's reading was corrected from rab-; there is certainly an erased ascender, possibly an added descender; Eyssenhardt read babulum [ut vid.], corrected to pabulum. 9 sagi contortis V, edd. Io -strabam. Isdemq; V I3 artior V, edd.; the MS is damaged where the a should be. I5 -les uisebatur V I6 lampade V, edd.

M 2V (I8.6.I6-I7)

$\begin{array}{rr}\text { Meiacarire nomine uenissemus, cui fontes dedere uo } & \text { I } \\ \text { cabulum gelidi lapsis accolis omnibus solum inremo } & 2 \\ \text { to secessu latentem inuenimus militem quioblatus } & 3 \\ \text { duci et locutus uaria prae timore ideoque suspec } & 4 \\ \text { tus adigente metu qui intentabatur pandit rerum } & 5 \\ \text { integram fidem docetque quod apud parisios na } & 6 \\ \text { tus in Galliis \& equestri militans turma uindictam } & 7 \\ \text { quondam commissi facinoris timensad persasabier } & 8 \\ \text { at profugus exindeque morum probitate spectata } & 9 \\ \text { sortita coniuge liberisque susceptis speculatorem } & \text { IO } \\ \text { se missum ad nostra saepe ueros nuntios reportasse } & \text { II } \\ \text { at nunc se a Tamsapore et Nohodare optimatibus } & \text { I2 } \\ \text { missum qui cateruas ductauerant praedatorum adeos } & \text { I3 } \\ \text { redire quae didicerat perlaturum. Post haec ad } & \text { I4 } \\ \text { iectis quae agi in parte diuersa norat occiditur Pro } & \text { I5 } \\ \text { inde curarum crescente sollicitudine indepassibus ci } & \text { I6 } \\ \text { tis Amidam pro temporis copia uenimus ciuitatem } & \text { I7 } \\ \text { postea secutis cladibus inclutam quoreuersis explor } & \text { I8 }\end{array}$

4 Line wholly lost due to the cutting of the folio. $8 \mathrm{p}$ [er]sas abierat $\mathrm{V} 9$ spectata $V$; there is an erased letter preceding the final $a$, but it is beyond recovery. I2 It is unfortunately impossible to see whether $M$ read Nohodareo, the erroneous reading of V. I4 posthaec V I7 imuns, the reading of Broszinski and Teitler, is a typo.

\section{Works cited}

Baehrens, W. A. (1925) 'Bericht über die Literatur zu Ammianus Marcellinus 19I0-I924', Bursians Jahresberichte 203, 45-90.

Bischoff, B. (I998-2014) Katalog der festländischen Handschriften des neunten Jahrhunderts, 3 vols., Wiesbaden. 
Broszinski, H. and Teitler, H. C. (I990) 'Einige neuerdings entdeckten Fragmente der Hersfelder Handschrift des Ammianus Marcellinus', Mnemosyne 43, 408-23.

Cappelletto, R. (1978) 'Niccolò Niccoli e il codice di Ammiano Vat. Lat. I873', BPEC 26, 57-84.

(I98I) 'Marginalia di Poggio in due codici di Ammiano Marcellino (Vat. Lat. I873 e Vat. Lat. 2969)', in Miscellanea Augusto Campana, Padua, I89-2II.

(1983) Ricuperi Ammianei di Biondo Flavio, Rome.

Clark, C. U. (Igo4) The text tradition of Ammianus Marcellinus, New Haven.

(ed.) (I9IO-I5) Ammiani Marcellini Rerum gestarum libri qui supersunt. Recensuit rhythmiceque distinxit C. U. Clark, adiuvantibus L. Traube et G. Heraeo, 2 vols., Berlin.

Dumville, D. (1995) 'The early mediaeval insular churches and the preservation of Roman literature: towards a historical and palaeographical reevaluation', in O. Pecere and M. D. Reeve (eds.), Formative stages of classical traditions: Latin texts from Antiquity to the Renaissance, Spoleto, 197-237.

Eyssenhardt, F. (I87I) Ammiani Marcellini Rerum gestarum libri qui supersunt, Berlin.

Harmon, A. M. (I9Io) The clausula in Ammianus Marcellinus, New Haven.

Hengst, D. den (2010) 'Vir utriusque litteraturae non vulgariter callens emunctaeque naris. Sur Ghelen, éditeur d'Ammien Marcellin', in L. Galli Milic and N. Hecquet-Noti (eds.), Historiae Augustae Colloquium Genevense in honorem Francisci Paschoud septuagenarii, Bari, 153-63. Reprinted in id., Emperors and historiography, ed. D. Burgersdijk and J. A. van Waarden, Leiden, 2010, 293-305.

Kelly, G. (2015) Review of J. den Boeft et al., Philological and historical commentary on Ammianus Marcellinus xxIx, Leiden, 2013, JRS 105, 457-8.

McKitterick, R. (2004) History and memory in the Carolingian world, Cambridge.

Merrill, W. A. (1926) 'The Italian manuscripts of Lucretius', University of California Studies in Classical Philology 9, 27-83 and 85-126.

Mommsen, T. (I872) 'Über den kritischen Apparat zum Ammianus', Hermes 6, 23 I-42.

Nissen, H. (I876) Ammiani Marcellini Fragmenta Marburgensia, Berlin.

Ott, R. L. and Longnecker, M. T. (2016) An introduction to statistical methods and data analysis, 7th edn, Boston.

Parkes, M. B. (1993) Pause and effect: an introduction to the history of punctuation in the West, Berkeley.

Pasquali, G. (1934) Storia della tradizione e critica del testo, Florence.

Pellegrin, E. (I99I) Les manuscrits classiques latines de la Bibliothèque Vaticane 3,1, Paris.

Petitmengin, P. (2006) 'Gelenius (Sigismundus) (I497?-I554)', in C. Nativel et al. (eds.), Centuriae Latinae II. Cent une figures humanistes de la Renaissance aux lumières, Geneva, 337-5I.

Reynolds, L. D. (1983) 'Ammianus Marcellinus', in id. (ed.), Texts and transmission, Oxford, 6-8.

Robinson, R. P. (1936) 'The Hersfeldensis and Fuldensis of Ammianus Marcellinus', University of Missouri Studies II, I8-40.

Saenger, P. (1997) Space between words: the origins of silent reading, Stanford.

Seyfarth, W. (I962) Der Codex Fuldensis und der Codex E des Ammianus Marcellinus, Berlin.

(ed.) (1978) Ammiani Marcellini Rerum gestarum libri qui supersunt. Edidit Wolfgang Seyfarth, adiuvantibus Liselotte Jacob-Karau et Ilse Ulmann, Leipzig.

Stover, J. (forthcoming a) 'Epitome de Caesaribus I.24 and Ovid's exile', CP.

(forthcoming b) 'Space as paratext: scribal practice in the medieval edition of Ammianus', in M. Teeuwen and I. Renswoude (eds.), The annotated book: early medieval pratices of reading and writing, Turnhout.

Traube, L. (1903) 'Die Ueberlieferung des Ammianus Marcellinus', Mélanges Boissier, Paris, 443-8. Reprinted in id., Vorlesungen und Abhandlungen. Volume III, Munich, I920, 33-8. 